\title{
Genetic and biochemical markers of hydroxyurea therapeutic response in sickle cell anemia
}

\author{
Danilo Grunig Humberto Silva ${ }^{1,4}$, Edis Belini Junior', Gisele Cristine de Souza Carrocini ${ }^{1}$, Lidiane de Souza Torres ${ }^{1}$, \\ Octávio Ricci Júnior ${ }^{2}$, Clarisse Lopes de Castro Lobo ${ }^{3}$, Claudia Regina Bonini-Domingos ${ }^{1}$ and \\ Eduardo Alves de Almeida ${ }^{*}$
}

\begin{abstract}
Background: Sickle cell anemia (SCA) presents a complex pathophysiology which can be affected by a number of modifying factors, including genetic and biochemical ones. In Brazil, there have been no studies verifying $\beta^{\mathrm{S}}$-haplotypes effect on oxidative stress parameters. This study evaluated $\beta^{\mathrm{S}}$-haplotypes and $\mathrm{Hb} \mathrm{F}$ levels effects on oxidative stress markers and their relationship with hydroxyurea (HU) treatment in SCA patients.

Methods: The studied group was composed by 28 SCA patients. Thirteen of these patients were treated with HU and 15 of them were not. We used molecular methodology (PCR-RFLP) for hemoglobin S genotype confirmation and haplotypes identification. Biochemical parameters were measured using spectrophotometric methods (Thiobarbituric-acid-reactive substances and Trolox equivalent antioxidant capacity levels, catalase and GST activities) and plasma glutathione levels by High-performance liquid chromatography coupled to electrochemical detection.

Results: We found the highest frequency of Bantu haplotype (48.2\%) which was followed by Benin (32.1\%). We observed also the presence of Cameroon haplotype, rare in Brazilian population and 19.7\% of atypical haplotypes. The protective Hb F effect was confirmed in SCA patients because these patients showed an increase in Hb F levels that resulted in a $41.3 \%$ decrease on the lipid peroxidation levels $(r=-0.74, p=0.01)$. Other biochemical parameters have not shown differential expression according to patient's haplotypes. Bantu haplotype presence was related to the highest lipid peroxidation levels in patients $(p<0,01)$, but it also conferred a differential response to HU treatment, raising $\mathrm{Hb} F$ levels in $52.6 \%(p=0.03)$ when compared with the group with the same molecular profile without HU usage.

Conclusions: SCA patients with Bantu haplotype showed the worst oxidative status. However these patients also demonstrated a better response to the treatment with HU. Such treatment seems to have presented a "haplotypedependent" pharmacological effect.
\end{abstract}

Keywords: Hemoglobin S, Beta-S-gene cluster haplotypes, Oxidative stress, Antioxidant capacity

\section{Background}

Sickle cell anemia (SCA) is a chronic and progressively debilitating medical condition featuring ongoing hemolytic anemia and recurrent acute vaso-occlusive events [1]. It is characterized by a clinical course highly variable, ranging from death in early childhood [2] to a normal life span with few complications [3]. This feature reflects the complex pathophysiology of SCA which can be affected by a number

\footnotetext{
* Correspondence: ealmeida@ibilce.unesp.br

${ }^{4}$ Department of Chemistry and Environmental Sciences, Sao Paulo State University-UNESP, Sao Paulo, Brazil

Full list of author information is available at the end of the article
}

of modifying factors including haplotype of $\beta$-globin gene cluster [4], coinheritance of polymorphisms associated with clinical aspects [5,6] and treatment response [7], hemoglobin fetal (Hb F) levels [8], chronic inflammation and oxidative states $[9,10]$ as well as gender [4].

There are five distinct haplotypes linked to the $\beta^{\mathrm{S}}$-mutation and they are known as Benin (Ben), Bantu or Central African Republic, Senegal (Sen), Cameroon (Camer) and Indian-Arab haplotypes. These ones are classified according to the geographical region in which they were originally identified [11,12]. Analysis of $\beta^{S}$ polymorphisms is of genetic and anthropologic interest, but it may also be related to

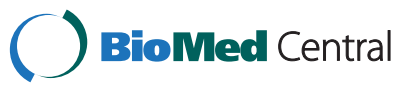


disease severity as well as variations in drug response $[13,14]$. Bantu haplotype has been associated with more severe disease outcome and a high organ damage incidence. Benin haplotype has been associated with intermediate disease severity. On the other hand, Senegal and Indian-Arab haplotypes have been associated with milder disease severity $[13,15]$ due to their higher $\mathrm{Hb} F$ levels related to the $\mathrm{C} \rightarrow \mathrm{T}$ mutation at position $-158 \mathrm{XmnI}$ in the ${ }^{\mathrm{G}} \gamma$-globin gene promoter region [15].

Hydroxyurea (HU) administration seems to be the best available treatment option for SCA patients $[1,16,17]$. HU is an antineoplastic drug which its main pharmacological action is to increase $\mathrm{Hb} F$ levels. It has other potentially beneficial effects including improved nitric oxide (NO) metabolism, reduced red cell-endothelial interaction and decreased erythrocyte density [1]. Although highly effective for most SCA patients, there is a considerable inter-patient variability creating a broad spectrum of $\mathrm{Hb} F$ induction $[1,18]$. HU mechanisms of action for $\mathrm{Hb} \mathrm{F}$ induction remain incompletely understood. $\mathrm{Hb} \mathrm{F}$ induction by $\mathrm{HU}$ has been correlated to cell cycle inhibition leading to activation of stress erythropoiesis [1,19-21]. Other studies have suggested that $\mathrm{Hb} \mathrm{F}$ induction by $\mathrm{HU}$ is mediated more specifically via nitric oxide-dependent transcriptional mechanisms $[22,23]$ and cyclic nucleotides $[24,25]$ and initial evidence for some epigenetic regulation [26].

Many studies have been carried out trying to establish a relation between $\beta^{S}$-haplotypes and SCA phenotype. These haplotype-phenotype associations are not definitely established and no clear correlation has emerged [6,27-29] to date, though. In Brazil, there have been no studies verifying $\beta^{S}$-haplotypes effect on oxidative stress parameters. Therefore this work aimed at studying $\beta^{S}$ haplotype effects and $\mathrm{Hb} F$ levels on oxidative stress markers and their relationship with HU treatment.

\section{Methods \\ Patients}

Eligible patients were 10 years or older at the beginning of the study and they were diagnosed with SCA. They all had access to the same medication protocol. The studied group was composed by 28 SCA patients (11 males and 17 females; mean age: 27.7 years old; range: $10-65$ years old) in clinical follow-up in Sao Jose do Rio Preto (SP) and Rio de Janeiro (RJ). All the patients are from the southeast region of Brazil.

All SCA patients were screened using a questionnaire. Pregnant, smokers or drinkers were excluded from the study, as well as anyone who had had a stroke, pain and/or hemolytic crisis or had received blood transfusion within two months prior to the start of the study. The medications used by SCA patients were previously checked and the ones taking any other medication known to affect the parameters analyzed (such as acetylsalicylic acid, antibiotics or vitamins) within $24 \mathrm{~h}$ of sample collection were also excluded. All subjects gave their informed consent and the study was reviewed and ethically approved by the Data Safety Monitoring Board (DSMB) according to Brazilian Regulations and Ethical Committee of Sao Paulo State University (0015.0.229.000-09).

\section{Biological samples}

Blood samples $(11 \mathrm{~mL})$ were collected through venipuncture in heparinized and ethylenediamine tetraacetic acid (EDTA) tubes. The heparinized blood $(7 \mathrm{~mL})$ was incubated for 20 $\min$ at $37^{\circ} \mathrm{C}$ and then centrifuged at $206 \mathrm{~g}$ for $20 \mathrm{~min}$ to separate plasma for Thiobarbituric-acid-reactive substances (TBARS) and Trolox equivalent antioxidant capacity (TEAC) analysis. The EDTA sample fraction $(4 \mathrm{~mL})$ was aliquoted: $2 \mathrm{~mL}$ used for the hemoglobinopathies tests, genotypic determination and catalase (CAT) and glutathione $S$-transferase (GST) enzymatic activities analysis and the other $2 \mathrm{~mL}$ were submitted to centrifugation at $825 \mathrm{~g}$ for 10 min to obtain plasma and then were frozen at $-80^{\circ} \mathrm{C}$ for glutathione (GSH) levels determination.

\section{Hemoglobin phenotypes, genotypes and $\beta^{S}$-globin haplotypes}

$\mathrm{Hb}$ identification was performed using electrophoresis on cellulose acetate $\mathrm{pH} 8.4$ and agar electrophoresis at $\mathrm{pH}$ 6.2. Hb fraction quantification was obtained using high performance liquid chromatography (HPLC) by the automated VARIANT ${ }^{\mathrm{mm}}$ equipment (Bio-Rad Laboratories, CA, USA) [30]. Cell morphology microscopic analysis was performed on the stained blood using May-GrünwaldGiemsa. In all patient samples, $\mathrm{Hb} \mathrm{S}$ genotype was developed by molecular analysis using PCR-RFLP. The segment amplification that encodes $\beta^{\mathrm{S}}$ gene was accomplished by specific primers and amplicon was cleaved by the DdeI restriction endonuclease (New England BioLabs, MA, USA) [31]. Beta globin haplotypes were determined through the PCR-RFLP analysis of the following polymorphic restriction sites: $\gamma G$ (Hind III), $\gamma$ A (Hind III), $\psi \beta$ (Hinc II), $3^{\prime} \psi \beta$ (Hinc II) and $5^{\prime} \beta$ (Hinf I), as previously described [32].

\section{Biochemical analysis}

Lipid peroxidation levels were assessed in heparinized plasma using TBARS assay [33]. Antioxidant capacity was also determined in heparinized plasma samples according to their equivalence to Trolox (6-hydroxy2,5,7,8-tetramethychroman-2-carboxylic acid) [34]. For total GST activity, blood samples were diluted in a 3.5 $\mu \mathrm{M}$ 2-mercaptoethanol $10 \mu \mathrm{M}$ NADP $2.7 \mathrm{mM}$ EDTA hemolyzing solution $(1: 20, \mathrm{v} / \mathrm{v})$ and then assayed using 1-chloro-2,4-dinitrobenzene (CDNB) as substrate at 340 $\mathrm{nm}$. The assay was carried out in $0.2 \mathrm{M} \mathrm{K}$-phosphate buffer $\mathrm{pH}$ 6.5, $1 \mathrm{mM}$ CDNB, $1 \mathrm{mM} \mathrm{GSH}\left(\varepsilon=9.6 \mathrm{mM}^{-1}\right.$ 
$\mathrm{cm}^{-1}$ ) [35]. For CAT activity analysis, blood samples were diluted in ultrapure water $(1: 50, \mathrm{v} / \mathrm{v})$ and then $10 \mu \mathrm{L}$ were used to measure CAT activity, by the decrease in absorbance at $240 \mathrm{~nm}\left(\varepsilon=0.04 \mathrm{mM}^{-1} \mathrm{~cm}^{-1}\right)$ due to consumption of $\mathrm{H}_{2} \mathrm{O}_{2}\left(10 \mathrm{mM} \mathrm{H} \mathrm{H}_{2}\right.$ in $1 \mathrm{M}$ Tris- $\mathrm{HCl}$ buffer $\mathrm{pH} 8.0$ containing $5 \mathrm{mM}$ EDTA) [36].

GSH concentration was determined in EDTA plasma samples using HPLC coupled to a coulometric electrochemical detector (Coulochem III ESA, Bedford, MA) [37]. Under these conditions, GSH clearly eluted in $\sim 6$ min. GSH was extracted from the plasma samples by adding perchloric acid to the plasma sample (10\% final concentration). After vigorous stirring and remaining $10 \mathrm{~min}$ on ice, the mixture was centrifuged at $825 \mathrm{~g}$ for $10 \mathrm{~min}$ at $4^{\circ} \mathrm{C}$. The extract was then filtered through Millex syringe filter units $(0.22 \mu \mathrm{m})$ and directly injected into the HPLC system. The calculations were based on a calibration curve previously constructed by injecting authentic GSH standards into HPLC system.

\section{Statistical analysis}

Statistical analysis was performed in groups with at least three individuals using the Statistica 9.0 software (Statsoft Inc.). Data were tested regarding normality and homogeneity of variances assumptions according to Shapiro-Wilk test and Levene's test, respectively. Groups that met the assumptions (parametric data) were compared by applying $t$ test or one-way ANOVA followed by Fisher's post hoc. Those groups that did not meet the assumptions (non-parametric data) were compared by Mann-Whitney test or Kruskal-Wallis followed by Dunn's post hoc test. In order to assess association degree between the studied variables, we used Pearson's correlation for parametric data and Spearman's rank correlation for non-parametric data. In order to assess age and gender influence on the values of oxidative stress markers, we classified SCA patients into two age groups ( $\leq 20$ and $>20$ years) and we applied factorial ANOVA.

Data were expressed as mean \pm standard deviation and $\mathrm{p}<0.05$ was considered statistically significant.
Table 1 Characterization of atypical $\beta^{\mathrm{s}}$-haplotypes alleles

\begin{tabular}{ccccccc}
\hline \multicolumn{7}{c}{ Restriction sites } \\
\hline$\beta^{\text {S}}$-Haplotypes & Xmn I & \multicolumn{1}{c}{ Hind III } & Hinc II & Hinf I \\
\hline & $5^{\prime} \gamma^{G}$ & $\gamma^{G}$ & $\gamma^{A}$ & $\psi \beta$ & $3^{\prime} \psi \beta$ & $5^{\prime} \beta$ \\
Atypical 1 & - & - & - & - & - & - \\
Atypical 2 & - & + & - & - & + & - \\
Atypical 3 & - & - & + & - & + & - \\
\hline
\end{tabular}

\section{Results}

Through $\beta^{\mathrm{S}}$-haplotypes molecular analysis we found nine different combinations of restriction sites, resulting in the following specific combinations: Bantu, Benin, Cameroon and three atypical. The atypical patterns were classified by the numbers 1,2 and 3, they do not fall into any of the classifications previously reported in the literature (Table 1).

We identified eight (28.5\%) patients with haplotype Bantu/Bantu, 10 (35.7\%) Bantu/Benin, two (7.1\%) Benin/ Benin, one (3.6\%) Benin/Cameroon, one (3.6\%) Bantu/ Atypical 1, one (3.6\%) Benin/Atypical 1, one (3.6\%) Benin/ Atypical 2, one (3.6\%) Benin/Atypical 3 and three (10.8\%) Atypical 2/Atypical 2. From 56 chromosomes analyzed, the allelic frequency observed was: $27(48.2 \%)$ alleles Bantu, 18 (32.1\%) Benin, one (1.8\%) Cameroon and 10 (19.7\%) Atypical, from the atypical ones, two (3.6\%) Atypical 1, seven (12.5\%) Atypical 2 and one (1.8\%) Atypical 3.

For biochemical parameters assessment, firstly we checked whether age and gender could influence the values of studied markers (TBARS and TEAC levels, GST and CAT enzyme activities and plasma GSH levels) to avoid biases. We found no statistically significant difference for any of the evaluated parameters, as shown in Table 2.

The influence of haplotypes and $\mathrm{HU}$ treatment over $\mathrm{Hb}$ F concentration and on biochemical markers was determined by subgroups formation - haplotype and HU use (+ $\mathrm{HU})$ and haplotype without $\mathrm{HU}$ use $(-\mathrm{HU})$. The values and/or mean of anallyzed parameters according to subgroup are presented in Table 3.

Between the subgroups submitted to statistical comparisons, we assessed haplotypes effect on SCA phenotypic

Table 2 Analysis of the age and gender interference on the biochemical markers values in SCA patients

\begin{tabular}{|c|c|c|c|c|c|c|}
\hline & \multicolumn{2}{|c|}{ Age $^{\#}$} & \multirow[t]{2}{*}{$P$ values* } & \multicolumn{2}{|c|}{ Gender ${ }^{\#}$} & \multirow[t]{2}{*}{$P$ values* } \\
\hline & $\leq 20$ years $n=09$ & $>20$ years $n=19$ & & Male $n=11$ & Female $n=17$ & \\
\hline TBARS (ng/mL) & $1452.94 \pm 699.00$ & $1577.07 \pm 539.85$ & 0.4950 & $1345.94 \pm 413.13$ & $1660.90 \pm 655.72$ & 0.0719 \\
\hline TEAC (mM) & $1.97 \pm 0.21$ & $2.03 \pm 0.15$ & 0.6737 & $2.01 \pm 0.23$ & $2.01 \pm 0.12$ & 0.7292 \\
\hline $\mathrm{GST}(\mathrm{U} / \mathrm{mL})$ & $1.77 \pm 0.94$ & $1.51 \pm 0.49$ & 0.2394 & $1.50 \pm 0.56$ & $1.64 \pm 0.72$ & 0.3757 \\
\hline CAT $(\mathrm{U} / \mathrm{mL})$ & $1660.80 \pm 525.41$ & $1912.16 \pm 517.83$ & 0.0957 & $1831.30 \pm 634.04$ & $1831.40 \pm 461.03$ & 0.7524 \\
\hline GSH $(\mu \mathrm{M})$ & $0.74 \pm 0.49$ & $0.70 \pm 0.39$ & 0.3644 & $0.59 \pm 0.52$ & $0.79 \pm 0.31$ & 0.2791 \\
\hline
\end{tabular}

${ }^{*}$ Comparisons were made by factorial ANOVA.

${ }^{\#}$ There were no significant interactions between independent variables: age and gender $(p>0.05)$. 
Table 3 Descriptive analysis of the $\beta^{\mathrm{S}}$-haplotypes interference in the phenotypic expression of SCA patients

\begin{tabular}{|c|c|c|c|c|c|c|c|}
\hline & & \multicolumn{6}{|c|}{ Parameters } \\
\hline & & Hb F (\%) & TBARS (ng/mL) & TEAC (mM) & GST $(\mathrm{U} / \mathrm{mL})$ & CAT $(\mathrm{U} / \mathrm{mL})$ & $\overline{\mathrm{GSH}}(\mu \mathrm{M})$ \\
\hline Haplotypes (+HU) & $\mathrm{n}$ & & & & & & \\
\hline Bantu/Bantu & 2 & 1.95 & 1201.18 & 2.17 & 1.26 & 1742.95 & 1.30 \\
\hline Bantu/Benin & $6^{*}$ & 17.42 & 1066.26 & 2.03 & 1.50 & 2294.01 & 0.62 \\
\hline Benin/Benin & 1 & 5.2 & 1616.62 & 2.17 & 1.44 & 2278.17 & 1.10 \\
\hline Benin/Camer & 0 & -—— & -—- & --— & --— & -—— & -—— \\
\hline Bantu/Atp1 & 0 & -—- & - - & -—— & - - & -—— & -—- \\
\hline Benin/Atp1 & 1 & 1.8 & 1524.30 & 2.20 & 1.20 & 1531.69 & 0.19 \\
\hline Benin/Atp2 & 1 & 8.4 & 1012.00 & 2.01 & 2.00 & 1084.51 & 0.22 \\
\hline Benin/Atp3 & 1 & 7.3 & 1216.92 & 2.10 & 1.92 & 1880.28 & 0.88 \\
\hline Atp2/Atp2 & 1 & 11 & 1308.00 & 1.97 & 1.51 & 1866.20 & 0.37 \\
\hline \multicolumn{8}{|l|}{ Haplotypes (-HU) } \\
\hline Bantu/Bantu & $6^{*}$ & 6.78 & 2284.33 & 1.93 & 2.03 & 1656.10 & 0.77 \\
\hline Bantu/Benin & $4^{*}$ & 6.68 & 1815.50 & 2.09 & 1.27 & 1842.43 & 0.84 \\
\hline Benin/Benin & 1 & 2.1 & 1222.00 & 2.09 & 1.65 & 2570.42 & 0.74 \\
\hline Benin/Camer & 1 & 4.8 & 934.00 & 1.90 & 2.00 & 996.48 & 0.70 \\
\hline Bantu/Atp1 & 1 & 3.2 & 1287.00 & 1.95 & 1.18 & 2017.61 & 0.87 \\
\hline Benin/Atp1 & 0 & -—— & -—- & -—- & -—- & -—— & - - - \\
\hline Benin/Atp2 & 0 & -—- & -—— & -—— & -—- & -—— & -—- \\
\hline Benin/Atp3 & 0 & - - - & -—- & -—- & -—- & -—- & -—— \\
\hline Atp2/Atp2 & 2 & 7.45 & 1576.00 & 1.77 & 1.45 & 1248.24 & 0.32 \\
\hline
\end{tabular}

$(+\mathrm{HU})$ : patients treated with $\mathrm{HU}$; $(-\mathrm{HU})$ : patients not treated with $\mathrm{HU}$; Camer: Cameroon; Atp: atypical.

*Subgroups subject to statistical comparisons.

expression markers, comparing Bantu/Bantu (-HU) with Bantu/Benin $(-\mathrm{HU})$ and we observed no statistical difference (Table 4). In order to prove the contribution of $\mathrm{HU}$ use on these markers, according to haplotypes subgroups, we compared Bantu/Benin (+HU) with Bantu/Benin $(-\mathrm{HU})$ and found an increase in $\mathrm{Hb} F$ levels in the treated subgroup $(\mathrm{p}<0.01)$ and consequent lipid peroxidation reduction $(\mathrm{p}=0.03)$ (Table 5).

The association degree among the studied markers showed that in patients with the same $\beta^{\mathrm{S}}$-haplotype (Bantu/ Benin), $\mathrm{HU}$ promoted an increase of $61.7 \%$ in $\mathrm{Hb} F$ values

Table 4 Influence of Bantu and Benin haplotypes on SCA phenotypic expression

\begin{tabular}{lccc}
\hline Modulators & $\begin{array}{c}\text { Bantu/Bantu (-HU) } \\
\mathbf{n}=\mathbf{0 6}\end{array}$ & $\begin{array}{c}\text { Bantu/Benin }(-\mathrm{HU}) \\
\mathbf{n}=\mathbf{0 4}\end{array}$ & $\begin{array}{c}\mathbf{P} \\
\text { values* }\end{array}$ \\
\hline Hb F $(\%)$ & $6.78 \pm 3.60$ & $6.67 \pm 6.37$ & 0.9731 \\
TBARS $(\mathbf{n g} / \mathrm{mL})$ & $2284.33 \pm 435.50$ & $1815.50 \pm 334.80$ & 0.1074 \\
TEAC $(\mathbf{m M})$ & $1.92 \pm 0.13$ & $2.08 \pm 0.18$ & 0.1465 \\
GST $(\mathbf{U} / \mathbf{m L})$ & $2.03 \pm 1.02$ & $1.27 \pm 0.63$ & 0.2245 \\
CAT $(\mathbf{U} / \mathbf{m L})$ & $1656.10 \pm 413.96$ & $1842.42 \pm 397.81$ & 0.4993 \\
GSH $(\boldsymbol{\mu M})$ & $0.77 \pm 0.37$ & $0.84 \pm 0.62$ & 0.8317 \\
\hline
\end{tabular}

$(-\mathrm{HU})$ patients not treated with HU. Mean \pm standard deviation.

* Comparisons were made by Mann-Whitney test.
(Figure 1A) and a decrease of $41.3 \%$ in lipid peroxidation levels (Figure 1B), according to a negative correlation found between these markers $(\mathrm{r}=-0.74, \mathrm{p}=0.01)$ (Figure 1C). The other evaluated biochemical parameters showed no differential expression or association.

Bantu haplotype is associated with the worst clinical outcomes in SCA. Therefore, to better address Bantu haplotype influence on oxidative stress markers and $\mathrm{HU}$ usage, we classified the patients into four sample groups:

Table 5 Influence of the HU use in SCA patients with the Bantu/Benin haplotype

\begin{tabular}{lccc}
\hline Modulators & $\begin{array}{c}\text { Bantu/Benin (+HU) } \\
\mathbf{n}=\mathbf{0 6}\end{array}$ & $\begin{array}{c}\text { Bantu/Benin (-HU) } \\
\mathbf{n}=\mathbf{0 4}\end{array}$ & $\begin{array}{c}\mathbf{P} \\
\text { values* }\end{array}$ \\
\hline Hb F (\%) & $17.41 \pm 3.10$ & $6.67 \pm 4.37$ & $0.0069^{\#}$ \\
TBARS $(\mathbf{n g} / \mathbf{m L})$ & $1066.26 \pm 495.09$ & $1815.50 \pm 334.80$ & $0.0303^{\#}$ \\
TEAC $(\mathbf{m M})$ & $2.02 \pm 0.16$ & $2.08 \pm 0.18$ & 0.6124 \\
GST $(\mathbf{U} / \mathbf{m L})$ & $1.49 \pm 0.62$ & $1.27 \pm 0.63$ & 0.5925 \\
CAT $(\mathbf{U} / \mathbf{m L})$ & $2294.01 \pm 297.29$ & $1842.42 \pm 397.81$ & 0.0725 \\
GSH $(\boldsymbol{\mu M})$ & $0.62 \pm 0.37$ & $0.84 \pm 0.62$ & 0.4981 \\
\hline
\end{tabular}

(-HU) patients not treated with $\mathrm{HU}$. (+HU) patients treated with $\mathrm{HU}$. *Comparisons were made by Mann-Whitney test.

"Indicates statistical difference $(\mathrm{p}<0.05)$. 


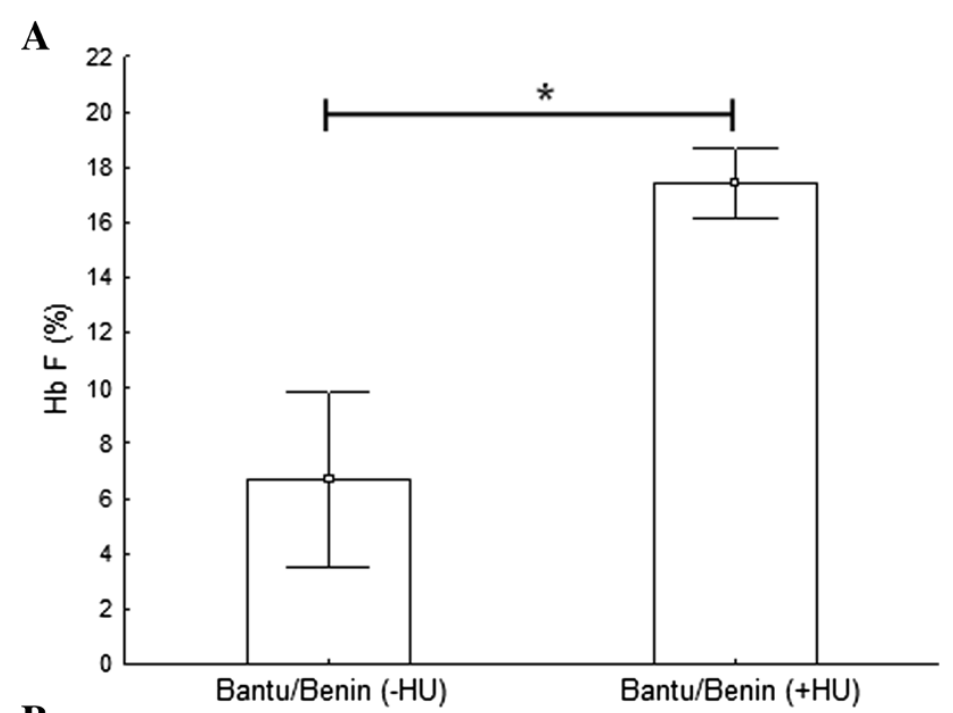

B
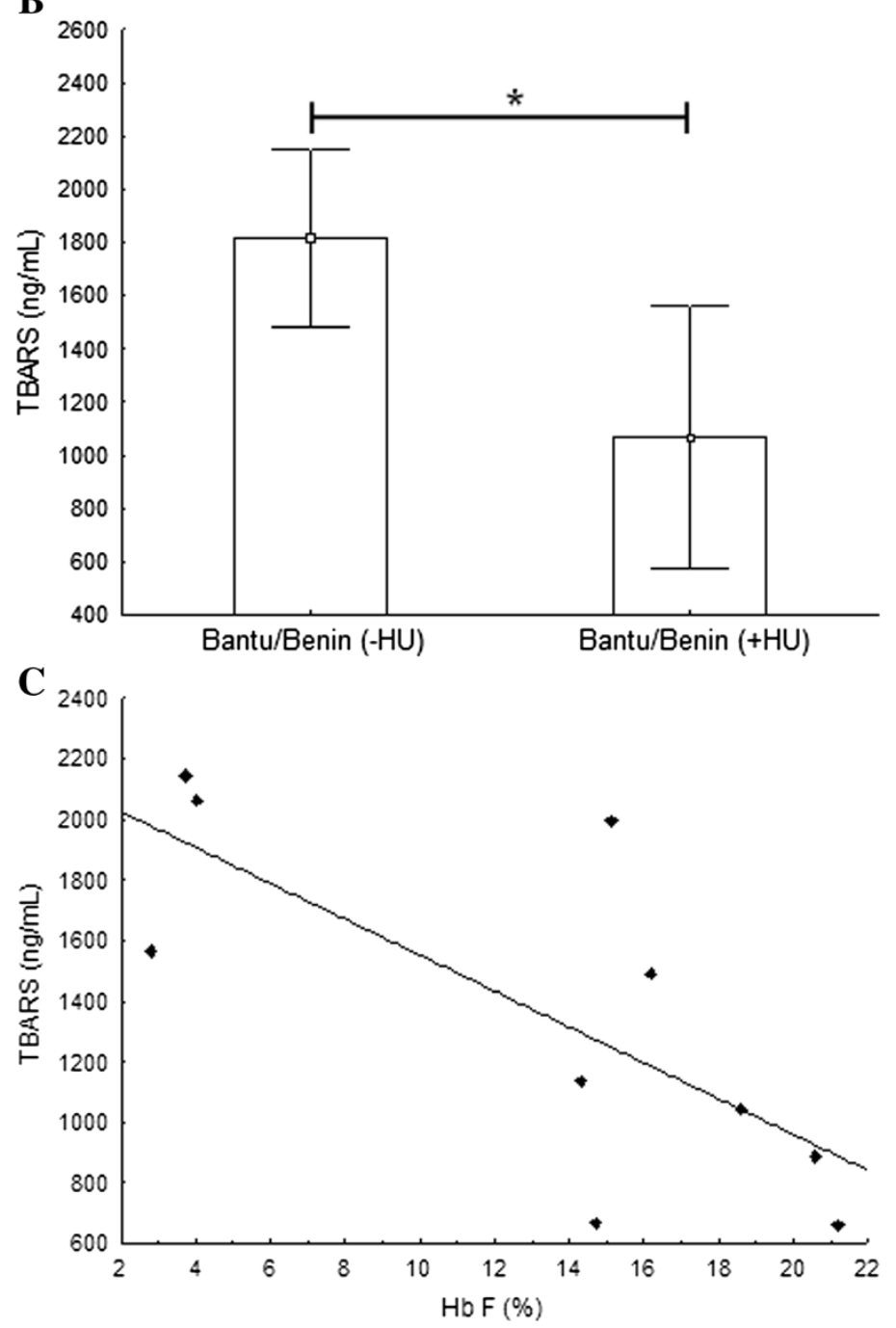

Figure 1 (See legend on next page.) 
(See figure on previous page.)

Figure $1 \mathrm{Hb} \mathrm{F}$ and lipid peroxidation levels in SCA patients with Bantu/Benin haplotype. A) Hb F levels were about 2.6 times higher in patients under $\mathrm{HU}$ treatment compared to those not treated ( $p=0.0069$; Mann-Whitney test). B) Lipid peroxidation levels showed 1.7 times lower in those patients on $\mathrm{HU}$ usage $(\mathrm{p}=0.0303$; Mann-Whitney test). C) Negative linear correlation between $\mathrm{Hb} \mathrm{F}$ and lipid peroxidation levels ( $r=-0.74 ; p=0.0156$; Spearman's rank test).

Group I. Patients with Bantu haplotype at least one chromosome without $\mathrm{HU}$ treatment. The haplotypes that comprised this group were Bantu/Bantu, Bantu/ Benin and Bantu/Atp1;

Group II. Patients with Bantu haplotype at least one chromosome and under HU treatment. The haplotypes were Bantu/Bantu and Bantu/Benin;

Group III. Patients without the Bantu haplotype a HU usage. This group was composed by haplotypes Benin/Benin, Benin/Camer, Atp2/Atp2;

Group IV. Patients without Bantu haplotype in any chromosome, but under HU usage. The haplotypes were Benin/Benin, Benin/Camer, Atp2/Atp2.

Table 6 summarizes obtained results from the comparisons between such groups for all evaluated parameters.

The haplotype sample group analysis also showed significant differences only in the $\mathrm{Hb} \mathrm{F}$ and lipid peroxidation markers. Bantu haplotype presence was related to the highest lipid peroxidation levels in patients $(\mathrm{p}<0.01)$ (Figure 2A), but also, it conferred a differential response to $\mathrm{HU}$ treatment, raising $\mathrm{Hb} F$ levels in 52.6\% ( $=0.03)$ when compared with the group with same molecular profile not treated (Group I). This treatment response was not observed in patients without Bantu haplotype (Figure 2B).

\section{Discussion}

Although SCA is one of the first disorders to be clearly defined at molecular level, genetic understanding of the basis for disease expression variability is still unclear [38]. Since $\beta^{S}$-haplotypes discovery as genetic modulators of phenotypic expression in SCA, several studies have been developed to determine haplotypes effect on SCA patients hematological and clinical features [13,27,38-41], but studies associating haplotypes with oxidative stress markers are scarce. This study, to our knowledge, yields a unique opportunity in which both genetic factor $\left(\beta^{\mathrm{S}}\right.$-haplotypes) and oxidative stress markers were simultaneously measured and correlated with $\mathrm{Hb}$ F levels and $\mathrm{HU}$ use in Brazilian SCA patients.

We found a higher frequency of Bantu haplotype followed by Benin. This distribution of $\beta^{\mathrm{S}}$-haplotypes was similar to other studies with Brazilian SCA patients from southeast region [39-44]. The chromosomes majority with $\beta^{S}$ gene has one of the five common haplotypes, although in every large series of SCA patients there is a minority of chromosomes $(5 \pm 10 \%)$ usually referred as "atypical" haplotypes [45]. We found $19.7 \%$ of atypical haplotypes, higher frequency than it is expected. None of the identified haplotypes during the study have had presence of XmnI polymorphic site, neither those haplotypes already described in the literature nor the atypical ones. Therefore, other genetic polymorphisms not targeted in this study should be involved in high $\mathrm{Hb} \mathrm{F}$ levels obtained in SCA patients not treated with HU.

Bantu/Benin haplotype was the most frequent. Therefore in these patients, we confirmed $\mathrm{Hb} \mathrm{F}$ protective effect provided by $\mathrm{HU}$ use. Once increasing $\mathrm{Hb} \mathrm{F}$ levels resulted in a decrease of the lipid peroxidation levels in accordance with our recent publications $[44,46]$. The protective effect is due to the increase in $\mathrm{Hb} F$ concentration that either inhibits or retards $\mathrm{Hb} \mathrm{S}$ polymerisation [47], leading to a decreased intravascular sickling and an increasing nitric oxide bioavailability [48]. These alterations result in a decreased oxidative stress with markedly decreased lipid peroxidation and increased activitylevels of antioxidants (SOD, GPx, catalase, and

Table 6 Relationship between the Bantu haplotype and HU treatment on SCA patients

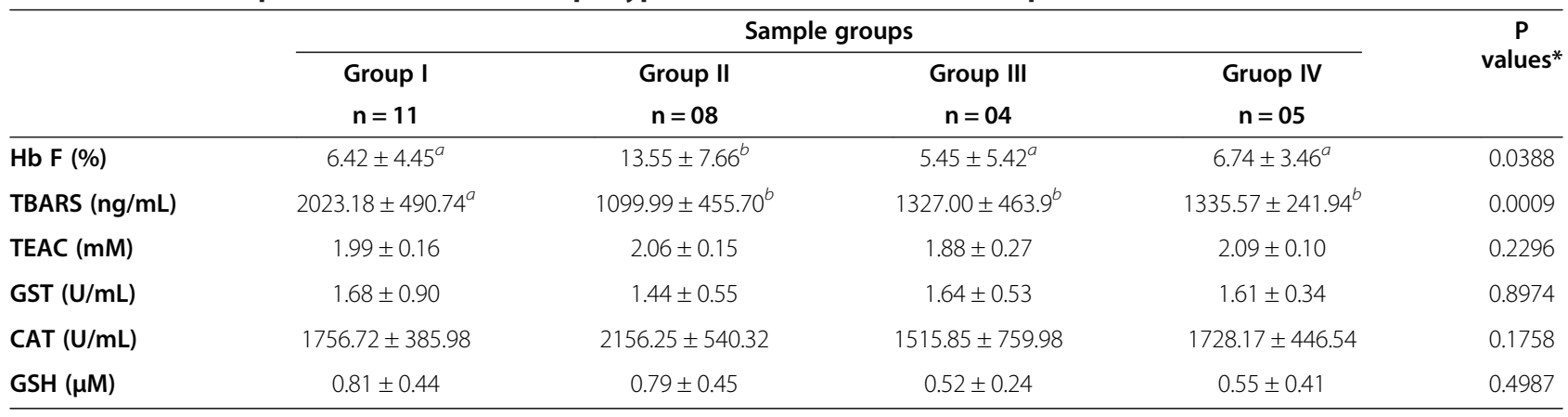

*Different letters indicate statistical differences (ANOVA followed by Fisher's post hoc test).

Group I: Bantu (-HU), Group II: Bantu (+ HU), Group III: any haplotype except Bantu (-HU), Group IV: any haplotype except Bantu (+ HU). 

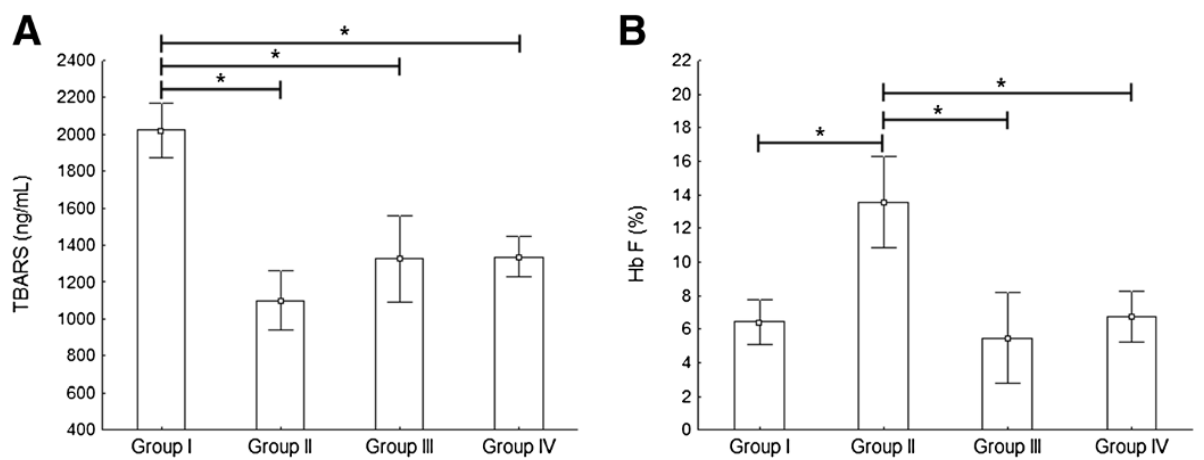

Figure 2 Analysis of Bantu haplotype effect and HU use on SCA phenotypic expression modulators. A) Lipid peroxidation showed its highest mean value in Group I compared to the others groups. B) Higher Hb F levels in patients of Group II compared to group with the same molecular profile not treated (Group I) and to the others evaluated groups. *Indicates statistical difference (ANOVA followed by Fisher's post hoc test). Group I: Bantu (-HU), Group II: Bantu (+ HU), Group III: any haplotype except Bantu (-HU), Group IV: any haplotype except Bantu (+ HU),

GSH) [48]. This antioxidant response was not observed though, according to the haplotype profile.

Bantu haplotype presence was related to the highest lipid peroxidation levels in patients, corroborating with the results obtained by Rusanova et al. [49]. The authors showed that SCA patients with Senegal and Indian-Arab alleles had the mild clinical outcomes associated with low oxidative status, whereas high oxidative stress was related to Benin and Bantu haplotypes, consequent severe phenotypes. On the other evaluated parameters (TEAC levels, CAT and GST activities and plasma GSH levels), we have not observed any significant haplotype influence. Thus, oxidative stress biomarkers analysis may be important in clinical condition evaluation of SCA patients, furthermore in therapeutic response monitoring among SCA patients under HU use.

Currently, many researches aimed at identifying interindividual genetic variations, underlying different pharmacological responses to drug use [50]. In SCA, this paradigm is being applied to elucidate vascular complications pathogenesis and to develop individualized therapies [6]. However, there is no stated relationship in the literature between differential response to $\mathrm{HU}$ treatment according to $\beta^{\mathrm{S}}$-haplotypes in SCA patients. Vicari et al. [51] showed, in contrast to previous reports [52-54], a significant increase in $\mathrm{Hb} F$ levels in SCA patients with Bantu haplotype after HU use, similar HU pharmacological response that we obtained in our studied group. As it is estimated that $40 \%$ of the patients do not respond to HU treatment [55] and Bantu haplotype is the most frequent in Brazilian SCA patients, this HU differential response should be carefully interpreted, according to Vicari et al. [51].

We hypothesized that this "haplotype-dependent" pharmacological effect of $\mathrm{HU}$ is due to the "highest stress erythropoiesis stimulation" in SCA patients with Bantu haplotype. The presence of Bantu haplotype is associated with a hyperoxidative status and consequent higher hemolytic levels and lower $\mathrm{Hb}$ concentrations, characteristics known to increase the circulating erythropoietin concentrations, which in turn stimulates erythropoiesis [56-58]. Based on HU cytotoxic effect which is beneficial in many ways; it targets rapidly dividing cells, which in red cells tend to be those ones with a high $\mathrm{Hb}$ $\mathrm{S}$ levels and favors the production of red cells with a high $\mathrm{Hb} \mathrm{F}$ levels, as these levels tend to arise from red cells that divide less rapidly [59]. This way, SCA patients with Bantu haplotype under HU use would have higher erythropoiesis stimulation, favoring production of red cells with a high $\mathrm{Hb} F$ levels. This hypothesis agrees with the observations from Gordeuk et al. [60]. The authors confirmed by multiple linear regression that lower hemoglobin concentration was correlated with higher erythropoietin concentration and higher $\mathrm{Hb} \mathrm{F}$ percentage among sickle cell disease patients. Therefore, even with a small sample size, our results have left perspectives for further studies to better address this hypothesis.

\section{Conclusion}

We provided evidence that Bantu haplotype presence seems to be an important predictor factor of oxidative stress and of differential response to HU use in SCA patients. We confirmed a hyperoxidative status among SCA patients. This status should be considered, at least partially, on clinical manifestations variety of these patients. Thus, the use of oxidative stress biomarkers may be important in the evaluation of clinical condition of SCA patients, furthermore in therapeutic response monitoring among SCA patients under HU use. We also suggest that the development of therapies to improve the redox status would be beneficial to reduce the severity of SCA.

\section{Competing interests}

The authors declare no competing financial or other relationship with other people or organizations interests. 


\section{Authors' contributions}

DGHS: data design, data acquisition, data analysis, statistical analysis, data interpretation and manuscript preparation. EBJ: technical assistance on molecular, biochemical and statistical analysis. GCSC: technical assistance in the standardization of molecular biology analysis. LST: technical assistance on biochemical analysis. ORJ: data provision and critical review of manuscript. CLCL: data provision and critical review of manuscript. CRBD: study concept and design and critical review of manuscript. EAA: study concept and design, guidance on standardization of the biochemical methods and critical review of the manuscript. All authors read and approved the final manuscript.

\section{Acknowledgments}

The authors would like to thank the following Brazilian foundations: Conselho Nacional de Desenvolvimento Científico e Tecnológico (CNPq) (grant 409691/2006-2), Fundação de Amparo à Pesquisa do Estado de São Paulo (FAPESP) (2006/03873-1), Coordenação de Aperfeiçoamento de Pessoal de Nível Superior (CAPES) and the Ministry of Health (grant MS 3072/2007) for their financial support, and Carolina Grünig Humberto da Silva for revising the English text.

\section{Author details}

'Department of Biology, Hemoglobin and Hematologic Genetic Diseases Laboratory, Sao Paulo State University-UNESP, Sao Paulo, Brazil. ²Department of Medicine, Sao Jose do Rio Preto Medical School-FAMERP, Sao Paulo, Brazil. ${ }^{3}$ Hematological State Institute "Arthur de Siqueira Cavalcanti"HEMORIO, Rio de Janeiro, Brazil. ${ }^{4}$ Department of Chemistry and Environmental Sciences, Sao Paulo State University-UNESP, Sao Paulo, Brazil.

Received: 17 April 2012 Accepted: 2 October 2013

Published: 9 October 2013

\section{References}

1. Ware RE: How I use hydroxyurea to treat young patients with sickle cell anemia. Blood 2010, 115:5300-5311.

2. Leikin SL, Gallagher D, Kinney TR, Sloane D, Klug P, Rida W: Mortality in children and adolescents with sickle cell disease: cooperative study of sickle cell disease. Pediatrics 1989, 84:500-508.

3. Serjeant GR, Higgs DR, Hambleton IR: Elderly survivors with homozygous sickle cell disease. N Engl J Med 2007, 356:642-643.

4. Kulozik AE, Wainscoat JS, Serjeant GR, Kar BC, Al-Awamy B, Essan GJ, et al: Geographical survey of beta S-globin gene haplotypes: evidence for an independent Asian origin of the sickle-cell mutation. Am J Hum Genet 1986, 39:239-244.

5. Steinberg MH, Adewoye AH: Modifier genes and sickle cell anemia. Curr Opin Hematol 2006, 13:131-136.

6. Steinberg $\mathrm{MH}$ : Predicting clinical severity in sickle cell anaemia. $\mathrm{Br} \mathrm{J}$ Haematol 2005, 129:465-481

7. Fertrin KY, Costa FF: Genomic polymorphisms in sickle cell disease: implications for clinical diversity and treatment. Expert Rev Hematol 2010 3:443-458.

8. Steinberg MH: Management of sickle cell disease. N Engl J Med 1999, 340:1021-1030.

9. Conran N, Franco-Penteado CF, Costa FF: Newer aspects of the pathophysiology of sickle cell disease vaso-occlusion. Hemoglobin 2009, 33:1-16.

10. Fibach $E$, Rachmilewitz $E$ : The role of oxidative stress in hemolytic anemia. Curr Mol Med 2008, 8:609-619.

11. Nagel RL, Fleming AF: Genetic epidemiology of the beta s gene. Baillieres Clin Haematol 1992, 5:331-365.

12. Pagnier J, Mears JG, Dunda-Belkhodja O, Schaefer-Rego KE, Beldjord C, Nagel $\mathrm{RL}$, et al: Evidence for the multicentric origin of the sickle cell hemoglobin gene in Africa. Proc Natl Acad Sci U S A 1984, 81:1771-1773.

13. Powars DR, Chan L, Schroeder WA: Beta S-gene-cluster haplotypes in sickle cell anemia: clinical implications. Am J Pediatr Hematol Oncol 1990, 12:367-374

14. Nagel RL, Fabry ME, Pagnier J, Zohoun I, Wajcman H, Baudin V, et al: Hematologically and genetically distinct forms of sickle cell anemia in Africa: the Senegal type and the Benin type. N Engl J Med 1985, 312:880-884.
15. Padmos MA, Roberts GT, Sackey K, Kulozik A, Bail S, Morris JS, et al: Two different forms of homozygous sickle cell disease occur in Saudi Arabia. Br J Haematol 1991, 79:93-98.

16. Aliyu ZY, Tumblin AR, Kato GJ: Current therapy of sickle cell disease. Haematologica 2006, 91:7-10.

17. Ware RE, Aygun B: Advances in the use of hydroxyurea. Hematology Am Soc Hematol Educ Program 2009:62-69.

18. Ware RE, Eggleston B, Redding-Lallinger R, Wang WC, Smith-Whitley K Daeschner $C$, et al: Predictors of fetal hemoglobin response in children with sickle cell anemia receiving hydroxyurea therapy. Blood 2002, 99:10-14.

19. Baliga BS, Pace BS, Chen HH, Shah AK, Yang YM: Mechanism for fetal hemoglobin induction by hydroxyurea in sickle cell erythroid progenitors. Am J Hematol 2000, 65:227-233.

20. Letvin NL, Linch DC, Beardsley GP, Mclntyre KW, Nathan DG: Augmentation of fetal-hemoglobin production in anemic monkeys by hydroxyurea. N Engl J Med 1984, 310:869-873.

21. Papayannopoulou T, De Torrealba RA, Veith $R$, Knitter $G$, Stamatoyannopoulos G: Arabinosylcytosine induces fetal hemoglobin in baboons by perturbing erythroid cell differentiation kinetics. science 1984, 224:617-619.

22. Cokic VP, Smith RD, Beleslin-Cokic BB, Njoroge JM, Miller JL, Gladwin MT, et al: Hydroxyurea induces fetal hemoglobin by the nitric oxidedependent activation of soluble guanylyl cyclase. J Clin Invest 2003, 111:231-239.

23. Lou TF, Singh M, Mackie A, Li W, Pace BS: Hydroxyurea generates nitric oxide in human erythroid cells: mechanisms for gamma-globin gene activation. Exp Biol Med (Maywood) 2009, 234:1374-1382.

24. Cokic VP, Andric SA, Stojilkovic SS, Noguchi CT, Schechter AN: Hydroxyurea nitrosylates and activates soluble guanylyl cyclase in human erythroid cells. Blood 2008, 111:1117-1123.

25. Keefer JR, Schneidereith TA, Mays A, Purvis SH, Dover GJ, Smith KD: Role of cyclic nucleotides in fetal hemoglobin induction in cultured CD34+ cells. Exp Hematol 2006, 34:1151-1161.

26. Walker AL, Steward S, Howard TA, Mortier N, Smeltzer M, Wang YD, et al: Epigenetic and molecular profiles of erythroid cells after hydroxyurea treatment in sickle cell anemia. Blood 2011, 118:5664-5670.

27. Powars D, Hiti A: Sickle cell anemia: beta s gene cluster haplotypes as genetic markers for severe disease expression. Am J Dis Child 1993, 147:1197-1202.

28. Powars DR: Sickle cell anemia: beta s-gene-cluster haplotypes as prognostic indicators of vital organ failure. Semin Hematol 1991, 28:202-208.

29. Steinberg $\mathrm{MH}$ : Genetic etiologies for phenotypic diversity in sickle cell anemia. ScientificWorldJournal 2009, 9:46-67.

30. Bonini-Domingos CR: Metodologias laboratoriais para o diagnóstico de hemoglobinopatias e talassemias. Sao Paulo, Brazil: NH; 2006:121.

31. Saiki RK, Scharf S, Faloona F, Mullis KB, Horn GT, Erlich HA, et al: Enzymatic amplification of beta-globin genomic sequences and restriction site analysis for diagnosis of sickle-cell anemia. Science 1985, 230:1350-1354.

32. Sutton M, Bouhassira EE, Nagel RL: Polymerase chain reaction amplification applied to the determination of beta-like globin gene cluster haplotypes. Am J Hematol 1989, 32:66-69.

33. Uchiyama M, Mihara M: Determination of malonaldehyde precursor in tissues by thiobarbituric acid test. Anal Biochem 1978, 86:271-278.

34. Re R, Pellegrini N, Proteggente A, Pannala A, Yang M, Rice-Evans C: Antioxidant activity applying an improved ABTS radical cation decolorization assay. Free Radic Biol Med 1999, 26:1231-1237.

35. Keen JH, Habig WH, Jakoby WB: Mechanism for several activities of glutathione S-transferases. J Biol Chem 1976, 251:6183-6188.

36. Beutler E: Red cell metabolism: a manual of biochemical methods. Ann Intern Med 1975, 83:919.

37. Rodriguez-Ariza A, Toribio F, Lopezbarea J: Rapid-determination of glutathione status in fish liver using high-performance liquid-chromatography and electrochemical detection. J Chromatogr B Biomed Appl 1994, 656:311-318.

38. Inati A, Taher A, Bou AW, Koussa S, Kaspar H, Shbaklo H, et al: Beta-globin gene cluster haplotypes and $\mathrm{HbF}$ levels are not the only modulators of sickle cell disease in Lebanon. Eur J Haematol 2003, 70:79-83.

39. Belisario AR, Martins ML, Brito AM, Rodriques CV, Silva CM, Viana MB: Betaglobin gene cluster haplotypes in a cohort of 221 children with sickle cell anemia or Sbeta-thalassemia and their association with clinical and hematological features. Acta Haematol 2010, 124:162-170. 
40. Figueiredo MS, Kerbauy J, Goncalves MS, Arruda VR, Saad ST, Sonati MF, et al: Effect of alpha-thalassemia and beta-globin gene cluster haplotypes on the hematological and clinical features of sickle-cell anemia in Brazil. Am J Hematol 1996, 53:72-76.

41. Gonçalves MS, Nechtman JF, Figueiredo MS, Kerbauy J, Arruda VR, Sonati MF, et al: Sickle cell disease in a Brazilian population from Sao Paulo: a study of the beta S haplotypes. Hum Hered 1994, 44:322-327.

42. Figueiredo MS, Silva MC, Guerreiro JF, Souza GP, Pires AC, Zago MA: The heterogeneity of the beta s cluster haplotypes in Brazil. Gene Geogr 1994, 8:7-12.

43. Zago MA, Figueiredo MS, Ogo SH: Bantu beta s cluster haplotype predominates among Brazilian blacks. Am J Phys Anthropol 1992, 88:295-298.

44. Belini-Junior E, Da Silva DG, De Souza TL, De Almeida EA, Cancado RD, Chiattone C: Oxidative stress and antioxidant capacity in sickle cell anaemia patients receiving different treatments and medications for different periods of time. Ann Hematol 2012, 91(4):479-489.

45. Srinivas R, Dunda O, Krishnamoorthy R, Fabry ME, Georges A, Labie D, et al: Atypical haplotypes linked to the beta $S$ gene in Africa are likely to be the product of recombination. Am J Hematol 1988, 29:60-62.

46. Silva DG, Belini-Junior E, Torres LS, Ricci-Junior, Lobo CC, Bonini-Domingos $C R$, et al: Relationship between oxidative stress, glutathione $S$-transferase polymorphisms and hydroxyurea treatment in sickle cell anemia. Blood Cells Mol Dis 2011, 47:23-28.

47. Poillon WN, Kim BC, Rodgers GP, Noguchi CT, Schechter AN: Sparing effect of hemoglobin $\mathrm{F}$ and hemoglobin $\mathrm{A} 2$ on the polymerization of hemoglobin S at physiologic ligand saturations. Proc Natl Acad Sci USA 1993, 90:5039-5043.

48. Dasgupta T, Fabry ME, Kaul DK: Antisickling property of fetal hemoglobin enhances nitric oxide bioavailability and ameliorates organ oxidative stress in transgenic-knockout sickle mice. Am J Physiol Regul Integr Comp Physiol 2010, 298:R394-R402.

49. Rusanova I, Escames G, Cossio G, De Borace RG, Moreno B, Chahboune M, et al: Oxidative stress status, clinical outcome, and beta-globin gene cluster haplotypes in pediatric patients with sickle cell disease. Eur J Haematol 2010, 85:529-537.

50. Collins FS, Green ED, Guttmacher AE, Guyer MS: A vision for the future of genomics research. Nature 2003, 422:835-847.

51. Vicari P, De Barretto MA, Figueiredo MS: Effects of hydroxyurea in a population of Brazilian patients with sickle cell anemia. Am J Hematol 2005, 78:243-244.

52. Charache S, Dover GJ, Moore RD, Eckert S, Ballas SK, Koshy M, et al: Hydroxyurea: effects on hemoglobin $\mathrm{F}$ production in patients with sickle cell anemia. Blood 1992, 79:2555-2565.

53. Costa FF, Arruda VR, Goncalves MG, Miranda SR, Carvalho MH, Sonati MF, et al: Beta S-gene-cluster haplotypes in sickle cell anemia patients from two regions of Brazil. Am J Hematol 1994, 45:96-97.

54. Steinberg MH, Lu ZH, Barton FB, Terrin ML, Charache S, Dover GJ: Fetal hemoglobin in sickle cell anemia: determinants of response to hydroxyurea: multicenter study of hydroxyurea. Blood 1997, 89:1078-1088.

55. Schnog JB, Duits AJ, Muskiet FA, Ten CH, Rojer RA, Brandjes DP: Sickle cell disease: a general overview. Neth J Med 2004, 62:364-374.

56. Ebert BL, Bunn HF: Regulation of the erythropoietin gene. Blood 1999, 94:1864-1877.

57. Lee K, Prehu C, Merault G, Keclard L, Roudot-Thoraval F, Bachir D, et al: Genetic and hematological studies in a group of 114 adult patients with SC sickle cell disease. Am J Hematol 1998, 59:15-21.

58. Nagel RL, Erlingsson S, Fabry ME, Croizat H, Susuka SM, Lachman H, et al: The Senegal DNA haplotype is associated with the amelioration of anemia in African-American sickle cell anemia patients. Blood 1991, 77:1371-1375.

59. Wiles N, Howard J: Role of hydroxycarbamide in prevention of complications in patients with sickle cell disease. Ther Clin Risk Manag 2009, 5:745-755

60. Gordeuk VR, Campbell A, Rana S, Nouraie M, Niu X, Minniti CP, et al: Relationship of erythropoietin, fetal hemoglobin, and hydroxyurea treatment to tricuspid regurgitation velocity in children with sickle cell disease. Blood 2009, 19(114):4639-4644.

doi:10.1186/1471-2350-14-108

Cite this article as: Silva et al:: Genetic and biochemical markers of hydroxyurea therapeutic response in sickle cell anemia. BMC Medical Genetics 2013 14:108.

\section{Submit your next manuscript to BioMed Central and take full advantage of:}

- Convenient online submission

- Thorough peer review

- No space constraints or color figure charges

- Immediate publication on acceptance

- Inclusion in PubMed, CAS, Scopus and Google Scholar

- Research which is freely available for redistribution

Submit your manuscript at www.biomedcentral.com/submit
C Biomed Central 